\title{
The Viability of Lactobacillus acidophilus Microencapsulated in Ca-Alginate Whey Protein Isolate Glycerol Bead Using Emulsification Method
}

\author{
Gisthananda Madyasta*, Purwadi, Imam Thohari and Abdul Manab \\ Department of Animal Product Technology, Animal Husbandry Faculty, University of \\ Brawijaya, Malang, East Java, Indonesia \\ *Corresponding author
}

\begin{tabular}{|c|c|}
\hline & A B S T R A C T \\
\hline Keywords & \multirow{5}{*}{$\begin{array}{l}\text { The purpose of this research was to determine the concentration ca-alginate, whey } \\
\text { protein isolate and glycerol. The treatments were P1 }(1: 1: 1) \text {; P2 }(1: 2: 1) ; \mathrm{P} 3(1: 3: 1) \\
\text { on the viability of the cells, PSA, cell distribution and shape with photograph and } \\
\text { the structure using Scanning Electron Microscopy (SEM). The data were subjected } \\
\text { to analysis of variance (ANOVA). The results showed that the concentration of ca- } \\
\text { alginate, whey protein isolate and glycerol as microencapsule materials gave no } \\
\text { significant differences (P>0.05) effect on the cell viability of encapsulated } \\
\text { Lactobacillus acidophilus and gave different particle size, cell distribution and } \\
\text { shapes photographs and the microstructure of encapsulated L. acidophilus. It } \\
\text { concluded that ca-alginate, whey protein isolate and glycerol as microcapsule } \\
\text { materials increased viability of } L \text {. acidophilus, better Particle Size of the beat and } \\
\text { the morphological structure is better and smoother. }\end{array}$} \\
\hline Viability, & \\
\hline $\begin{array}{l}\text { Lactobacillus } \\
\text { acidophillus, } \\
\text { Microencapsule, } \\
\text { Ca-alginate, Whey } \\
\text { protein isolate, } \\
\text { Glycerol. }\end{array}$ & \\
\hline Article Info & \\
\hline $\begin{array}{l}\text { Accepted: } \\
\text { 17 June } 2017 \\
\text { Available Online: } \\
10 \text { July } 2017\end{array}$ & \\
\hline
\end{tabular}

\section{Introduction}

Lactobacillus acidophillus recognized as probiotic bacteria, it has good contribution for human health such as improving digestion and gives immunity. Probiotic bacteria will work optimally when it contains living cells that persist as it passes through the digestive tract with the high acidity of the stomach and survived on the food processing, storage, and has a good organoleptic.

The working principle of probiotic bacteria in the body that there is a capability in solving the long chain of nutrients (carbohydrates, protein, fat) by enzymes owned.
The problem of probiotics application in the food product was the sensitivity of probiotic to environmental conditions (Carvalho et al., 2004) and its resistency through stomach and digestive tract. Therefore, probiotics survival need a protection method through microencapsulation. Microencapsulation is a covering technique in order to protect the cells from extreme environments (Capela et al., 2007). The successive of microencapsulation depends on the suitability of the membrane of the microparticles, when bacterial cells that can live after the microencapsulation process, microencapsulation must remain intact when 
environment conditions are unfavorable for bacterial cells (Islam et al., 2010).

Microencapsulation requires ingredients in forming the covering (bead). The material that can be used is alginate because it has ability to form egg-box arrangement that can be utilized as coating material of encapsulation process (Qurrat-ul-Ain et al., 2003). Alginate gave more optimum protection properties when whey protein isolate was added. The addition of whey protein ingredients is widely used as a protective wall in encapsulation (Chen et al., 2014) and encapsulation using less fortified alginates to protect bacteria from acidic environments (Sultana, 2000).

The microencapsulated material may be combined with cryoprotectant. Combination with glycerol (cryoprotectan) can be used as internal protection by uphold the cell membrane while microencapsulation can be used as protection from outside (Widati et al., 2007) and it can be used as cryoprotectan because its ability to prevent the occurrence of crystallization of ice at freezing point and able to form edible film to form a layer protector.

Emulsion techniques often used in lactic acid bacteria encapsulation are continuously produced in large scale form. According to Talwalkar and Kailasapathy (2003) the emulsion method will produce smaller encapsulation bead sizes as a sign that the bead size or the distribution of cells within the bead is more widespread, resulting in more number of cells being produced than the method of extraction.

In a recent research (Purwandhi et al., 2007) in two-layered encapsulation technique using ca-algianat with skim milk on emulsion method prodused more cell numbers when compared to single layer encapsulation and smaller bead size than the method of the extraction.
The aim of this study was to investigated the use of a combination of glycerol as cryoprotectant material with ca-alginate and whey protein isolates as microcapsule materials using emulsification method on the cell viability, bead size (PSA), and microscopic observation.

\section{Methods and materials}

\section{Materials}

Pure cultured Lactobacillus acidophillus was purchased from agricultural technology faculty laboratory, Brawijaya University, MRS Broth (Oxoid). MRS agar (Oxoid), Alginate, $\mathrm{NaCl}$, whey isolate Protein, Glycerol (Merck), paraffin oil, Span 85 (Merck), $\mathrm{CaCl} 2$ (Merck), Pepton (Oxoid), sodium citrate (Merck), Sodium citrate (Merck) and distilled water.

\section{Encapsulation process}

The encapsulation process according to the method of Song et al., (2013) with several modification. Sodium alginate $1.5 \%(\mathrm{w} / \mathrm{v})$ is in $0.9 \%(\mathrm{w} / \mathrm{v}) \mathrm{NaCl}$ filtered and sterilized at $121^{\circ} \mathrm{C}$ for $15 \mathrm{~min}$. Whey protein isolate powder sterilized at $110^{\circ} \mathrm{C}$ for $10 \mathrm{~min}$ and dissolved in sterile distilled water. Glycerol dissolved in distilled water at a concentration of $6 \%$ and sterilized at $121^{\circ} \mathrm{C}$ for $15 \mathrm{~min}$. Alginate powder, whey protein isolate and glycerol mixed well with based ratio (1: 1: 1); (1: 2: 1); (1: 3: 1) as P1, P2 and P3 treatment respectively, entered into an emulsion using $50 \mathrm{ml}$ of paraffin oil and $0.5 \%$ (v/v) span 85 and stirred for 30 minutes at 200rpm. Add slowly $10 \mathrm{ml}$ of $0.05 \mathrm{M} \mathrm{CaCl} 2$ to the emulsion. Centrifuge for 10 minutes at $1000 \mathrm{rpm}$ and the supernatant discarded.

\section{Cell viability}

Cell viability of encapsulation that is ready to be added to a solution of sodium citrate 0.055 
$\mathrm{mol} / \mathrm{L}$ in order to detach the cells from the bead. Cell viability calculated using the TPC (Song et al., 2013).

\section{Particle size analysis}

The size of the microcapsule was measured using particle size analyser (CILAS 1090D). $0,1 \mathrm{ml}$ of Lactobacillus acidophillus dissolved in $0,9 \mathrm{ml}$ of distilled water and observed using particle size analyser (Chun, Kim, Hee-cho, 2014).

\section{Optical microscopy}

Optical microscopy using microscope BX 35 to find out the photograph cell distribution and shape of the microcapsule (Chum et al., 2014)

\section{Scanning electron microscopy}

The morphologies structure and shape of the microcapsule were evaluated using Scanning Electron Microscopy (SEM). Lactobacillus acidophillus microencapsule was dried using freeze drying for 5 hours (Chun, Kim, Heecho, 2014). The dried microcapsule were placed on specimen aluminium stub with the help of double sided sticky and coated by sputter (Zanjani et al., 2013), the microstructure was observed using SEM.

\section{Statistical analyses}

The statistical differences among the experimental data were analyzed using analysis of variance (ANOVA).

\section{Results and Discussion}

\section{Cell viability}

Viability is a survival parameter of a microbe that can live after treatment. Based on the result of variance analysis showed that microencapsulation quality of Lactobacillus acidophillus using ca-alginate-WPI-glycerol with emulsification method at different concentration showed No significant differences $(\mathrm{P}>0.05)$ were found on cell viability can be seen in table 1 .

Based on the analysis of variance indicate that microencapsulation of Lactobacillus acidophillus using ca-alginate-WPI-glycerol at higher concentration produced higher cell viability at P2, however slight lower at P3. The treatment $\mathrm{P} 1, \mathrm{P} 2$ and $\mathrm{P} 3$ gave cel viability 10.836, 10.853 and $10.781 \quad(\mathrm{cfu} / \mathrm{ml})$, respectively. The decrease in cell viability on P3 probably due to the higher concentration of whey protein less able to form a perfect microencapsulation protector so that the structure of microencapsule becomes weaker and fragile.

The viability of cells will increase due to the nature of the whey protein ability to entrapp bacterial cells into the microencapsulation. According to Heidebach et al., (2009b) that whey proteins are capable to forming excellent solid gelation despite differences in the encapsulation techniques and the ability of probiotics to capture into the gel is very easy. Cell viability decreases as milk protein shrinks as a result of the effect of excessive protein-specific concentrations on the surface layer make it less capable to gel formation (Fäldt and Bergenstål, 1994). Whey proteins are often biodegradable and protective derivatives of proteins are susceptible to cell release when the concentrations used are too high (Solanki et al., 2013). The emulsion technique is carried out through emulsion droplets and to entrap of probiotic bacteria to enhance the survival of microorganism cells under extreme environmental conditions according to the type of emulsifier (Chavarri et al., 2012). According to Heidebach (2009a) the emulsion technique in encapsulation using milk protein ingredients can provide good cell viability. This is due to rennet in milk 
containing probiotic cells and emulsification to the oil and then this method is modified by replacing rennet with transglutaminase that allows crosslink with milk protein.

\section{Particle size analysis}

The purpose of this study is to measure the size of particle size in microencapsulation that is to detect the quality of bacterial cells that are protected using microencapsulated materials during food processing and in the digestive tract (Cabuk and Harsa, 2015). The results showed that microencapsulation quality of Lactobacillus acidophillus using ca-alginate- WPI-glycerol by emulsification method with different concentration to particle size of bead can be seen in table 2 .

The results of table 2 indicate that the particle size form is expressed in $10 \%, 50 \%, 90 \%$ and span values used as the final value of the overall particle size. The higher value of the span indicates that the particle size is larger. The results indicate that the increasing concentration of ca-alginate-WPI-glycerol produced higher microencapsule particle size at P2 and P3 treatment compared to P1 treatment it indicates that there is an increaseing in thickening in the protective structural layer. The particle size of P3 treatment slight decreased than P1 treatment may be due to the higher concentration of WPI, causing weaker microcapsule formation and smaller particle size. Microencapsulation using emulsification method is capable to producing micrometer-sized particle size.

The emulsification technique in the encapsulation process is one of the recommended methods of forming a capsule bead at less than $1000 \mu \mathrm{m}$ but has difficulties when produced in large quantities (Rosasflores et al., 2013). Emulsion techniques require several chemicals and oil separation steps (Sohail et al., 2011) in addition to the coating materials used in the enclosure process as well as essential ingredients for its successful encapsulation process (Chum et al., 2014).

The size of the capsule beads produced by the emulsion method has an effect on the cell dispersion. According to Talwakar and Kailasapathy (2003) that the size of expanding beads of capsules having variations sizes causes the spreading of cells in the capsule unevenly and added by Mortazavian et al., (2007) that the unequal size of the capsule also gives The sensory organoleptic effect on the final product on the size of the capsule diameter 1000-3000 $\mu \mathrm{m}$.

\section{Optical microscopy}

The result of this research, it is shown that the microencapsulation of $L$. acidophillus using ca-alginate-WPI-glycerol with emulsification method at different concentration observed using BX 35 microscope. The result of microscopic observation can be seen in figure 1.

Microscopic observations using the BX 35 microscope that $\mathrm{P} 1, \mathrm{P} 2$ and $\mathrm{P} 3$ of different concentrations are capable of forming spheres identified as encapsulation and in the presence of Lactobacillus acidophillus bacterial cells. The arrows on the result of observation number 1 are marked as protector while the arrow number 2 as the protected core material is Lactobacillus acidophillus bacterial cell.

Several layers of encapsulation derived from encapsulation materials are essential for forming a barrier in protecting the core material (bacterial cell) against extreme environments (Solanki et al., 2013) So that the type and microencapsulation material produced is influenced by coating materials, particle size, and number of living cells. 
There are several forms of encapsulation according to Zuidam and Nedovic (2010) namely 1 . Reservoir is a type of matrix that has several layers around the core material. 2. Matrix is a type of matrix that has cells scattered in the carrier material and on the surface. 3. Coated matrix is the type of matrix combination between multiple layer matrices and scattered cells.

Table.1 The viability cell of Lactobacillus acidophilus using Ca-alginate whey protein isolate glycerol (log $10 \mathrm{Cfu} / \mathrm{ml})$

\begin{tabular}{|c|c|}
\hline Treatment & $\mathrm{Cfu} / \mathrm{ml}$ \\
\hline P1 (1:1) & $10,836 \pm 0,081^{\mathrm{a}}$ \\
\hline P2 (1:2) & $10,853 \pm 0,049^{\mathrm{a}}$ \\
\hline P3 (1:3) & $10,781 \pm 0,080^{\mathrm{a}}$ \\
\hline
\end{tabular}

Table.2 Particle size of Lactobacillus acidophilus bead

\begin{tabular}{|c|c|c|c|c|}
\hline & PSA $(\mu \mathrm{m})$ & PSA $(\mu \mathrm{m})$ & PSA $(\mu \mathrm{m})$ & \multirow{2}{*}{ SPAN } \\
\hline Treatment & $10 \%$ & $50 \%$ & $90 \%$ & \\
\hline P1 $(1: 1)$ & 9,42 & 62,90 & 121,30 & 1,77 \\
\hline P2 $(1: 2)$ & 18,13 & 110,68 & 362,77 & 3,11 \\
\hline P3 $(1: 3)$ & 14,55 & 110,28 & 354,29 & 3,08 \\
\hline
\end{tabular}

Fig.1 The photograph of L. acidophilus bead using BX 35 optical microscope

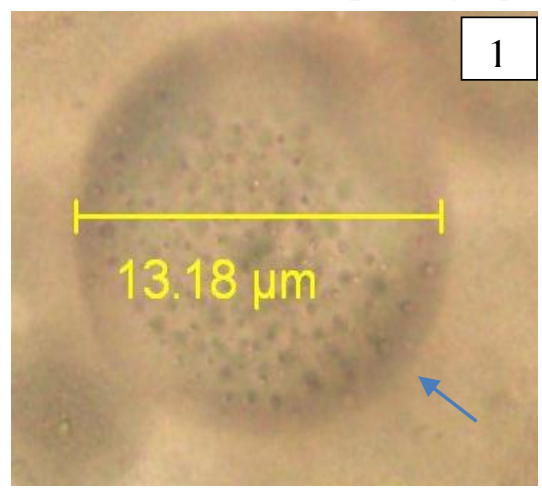

P1

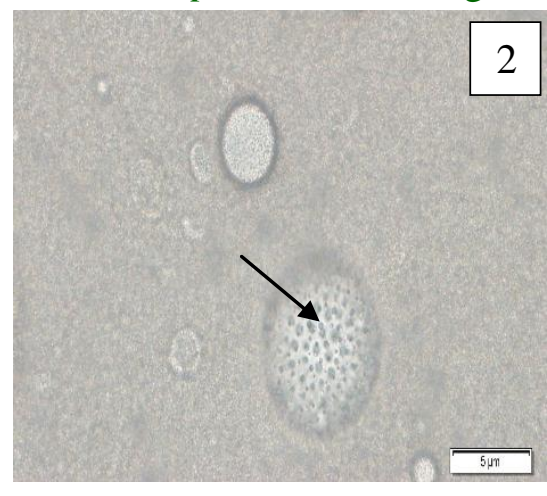

$\mathrm{P} 2$

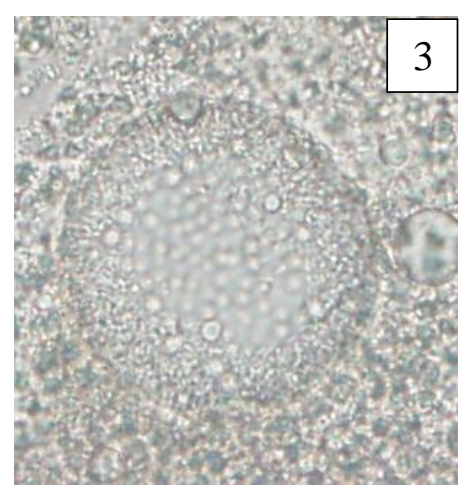

P3

Fig.2 The microstructure of L. acidophilus bead using SEM

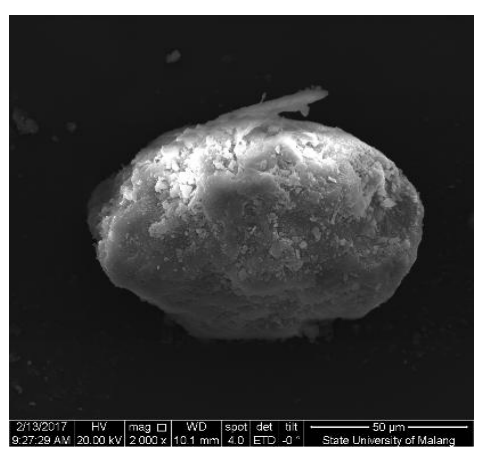

P1

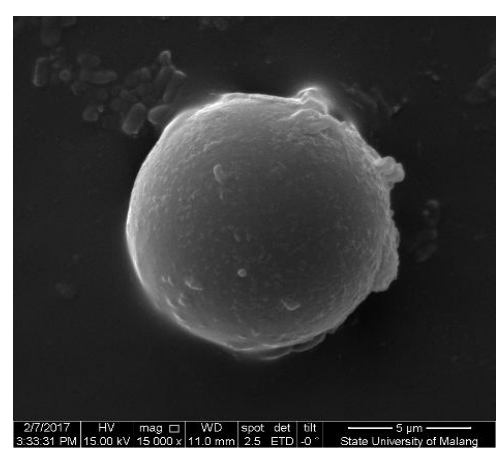

P2

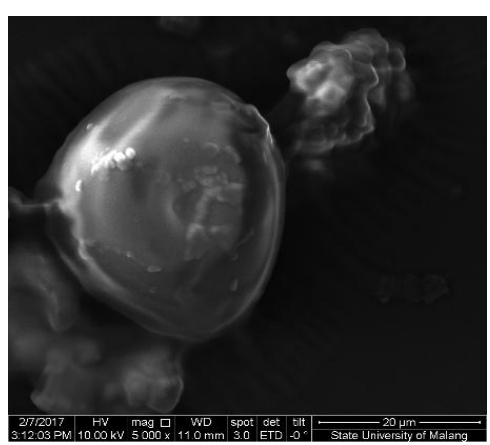

P3 


\section{Scanning electron microscopy}

Encapsulated L. acidophillus required a morphological examination through microscopic analysis by scanning electron microscopy (SEM) in order to know the formation of bacterial cell protection that would be protected to have a surface structure capable of enveloping bacterial cells either.

The result showed that microencapsulation quality of L. acidophillus using ca-alginateWPI-glycerol by emulsification method at different concentration was done microscopically observation using Scanning Electron Microscopy. The microstructure observations using Scanning Electron Microscopy can be seen in figure 2 .

The result of the research that $\mathrm{P} 1$ has a surface gel structure that is not smooth, ovalshaped and easily fragile. At P2 it has a smooth, round, solid, and there are some nonentangled bacteria (arrows) indicating that small bead sizes can trap cells better when compared to large bead sizes. At P3 the surface structure appears smooth, round, and a thin protective structural layer indicating that the size of the bead is so large that the cells inside the bead are not completely suspect and the number of cells produced is less. This indicates that the P2 encapsulation treatment using ca-alginate whey protein isolate glycerol (1:2:1) with emulsification method is able to provide cell-celling useful for protecting cells from environment unfavorable for cell survival.

Research by Ayama et al., (2014) that the calcium alginate form contains Lactobacillus plantarum CM53 microscopically through SEM in the form of spherical, cracked and cleft but when 3D observations show alginate able to entrap Lactobacillus plantarum CM53.
The microcapsule structure produced by sodium alginate, xanthan gum, alginate and chitosan will produce microcapsules with smooth surfaces while the material is mixed with the dairy material will result in slow gelforming properties and the irregularly produced surface structure (Ainsley et al., 2005). The gel structure of a brittle to dense bead can occur during the encapsulation treatment process. These different gel structures can be attributed to faster and slower stirring processes and the concentrations of the materials used make different gel structures (Guerin et al., 2003). The alginate material used in encapsulation is capable to producing small rounded bead surfaces such that able to protect bacterial cell Lactobacillus acidophillus (Mokarrom et al., 2009).

It concluded that ca-alginate-WPI-glycerol as microcapsule materials increased the viability of $L$. acidophilus, and gave better particle size of the bead and the morphological structure is better and smoother.

\section{References}

Ainsley, R.A., Vuillemard, J.C., Britten, M., Arcand, Y., Farnworth, E., and Champagne, $\quad$ C.P. 2005. Microentrapment of probiotic bacteria in a $\mathrm{Ca}\left(2^{+}\right)$- induced whey protein gel and effects on their viability in a dynamic gastro-intestinal model. $J$. Microencapsulation, 22: $603-619$.

Ayama, H., Sumpavol, P., and Chanthachum, S. 2014. Effect of encapsulation of selected probiotic cell on survival in simulated gastrointestinal tract condition. J. Sci. Technol., 36(3): 291299.

Cabuk, B. and Harsa, S.T. 2015. Protection of Lactobacillus acidophillus NRRL-B 4495 under in vitro gastrointestinal conditions with whey protein/pullulan 
microcapsules. J. Biosci. Bioengi., Issues 6/120: 650-656.

Capela, P. and Shah, N.P. 2006. Effect of cryoprotectants, prebiotics and microencapsulation on survival of probiotic organisms in yoghurt and freeze-dried yoghurt. Food Res. Int., 39(203-211).

Carvalho, A.S., Silva, J., Ho, P., Teixera, Malcata, F.X and Gibbs, P. 2003. Effects of addition of sucrose and salt and starvation upon thermotolerance and survival during storage of freeze dried Lactobacillus bulgaricus J. Dairy Sci., 68(8): 2538-2541.

Chavarri, M., Maranon, I., and Villaran, M.C. 2012. Encapsulation technology to protect probiotic bacteria. Intech Open Sci., page 511.

Chen, M.Y., Zheng, W., Dong, Q-Y., Li, Z.H., Shi, L.E., and Tang, Z.X. 2014. Activity of encapsulated Lactobacillus bulgaricus in alginate-whey protein microspheres. Brazilian Arch. Biol. Technol. Int. J., 57(5): 736-741.

Chum, H., Kim, C.H., and Cho, Y.H. 2014. Microencapsulation of Lactobacillus plantarum DKL 109 using external ionic gelation method. Korean J. Food Sci., 34(5): 692-699.

Fäldt, P., and Bergenståhl, B. 1994. The surface composition of spray-dried protein-lactose powders. Colloids Surf A. Physicochem Aspects, 90: 183-190.

Guerin, D., Vuillemard, J.C., and Subirade, M. 2003. Protection of Bifidobacteria encapsulated in polysaccharide-protein gel bead against gastric juice and bile. $J$. Food Protection, 66(11): 2076-2084.

Heidebach, T., Forst, P., and Kulozik, U. 2009a. Microencapsulation of probiotic cells by means of rennet-gelation of milk proteins. Food Hydrocolloids, 23: 1670-1677.

Heidebach, T., Först, P., and Kulozik, U. 2009b. Transglutaminase-induced caseinate gelation for the microencapsulation of probiotic cells. Int. Dairy J., 19: 77-84.

Islam, Ariful, M., Yun, C., Choi, Y. and Cho, C. 2010. Microencapsulation of live probiotic bacteria. J. Microbiol. Biotechnol., 20(10): 1367-1377.

Mokarram, R.R., Mortazavi, S.A., Najafi, H and Shahidi, F. 2009. The influence of multi stage alginate coating on survivability of potential probiotic bacteria in simulated gastric and intestinal juice. Food Res. Int., 42: 1040-1045.

Mortazavian, A.M., M.R. Ehsani., S.M. Mousavi., K. Rezael., S. Sohrabvandi., and J.A. Reinheimer. 2007. Effect of Refrigerated Storage Temperature on The Viability of Probiotic Microorganisms in Yogurt. Int. J. Dairy Technol., 60(2): 123-127.

Purwandhi, S., Sulandra, M., and Rahayu, E. 2007. The thermal stability of the probiotic agent $L$. acidophilus SNP 2 encapsulated the method of extraction and emulsion. Seminar Nasional Teknologi, (SNT 2007): E1-E6.

Qurrat-ul-Ain, Sharma, S., Khuller, G.K., and Garg, S.K. 2003. Alginate-Based Oral Drug Delivery System for Tuberculosis: Pharmacokinetics and Therapeutic Effects. J. Antimicrobial Chemother., 51: 931- 938.

Rosas-Flores, W., Ramos-Ramirez, E.G., and Salazar-Montoya, J.A. 2013. Microencapsulation of Lactobacillus helveticus and Lactobacillus delbrueckii using alginate and gellan gum. Carbohydr. Polym., 98: 1011-1017.

Sohail, A., Turner, M.S., Coombes, A., Bostrom, T., and Bhandari, B. 2011. Survivability of probiotics encapsulated in alginate gel microbeads using a novel impinging aerosols method. Int. J. Food Microbiol., 145: 162-168.

Solanki, H., Pawar, D., Shah, D., Prajapati, 
V., Jani, G., Mulla, A., and Thakar, P. 2013. Development microencapsulation delivery system for long-term preservation of probiotics as biotherapeutics agent. Biomed. Res. Int.

Song, H., Yu, W., Gao, M., and Liu, X. 2013. Microencapsulated probiotics using emulsification technique coupled with internal or external gelation process. $J$. Carbohydrate Polymers, 96: 181-189.

Talwalkar, A. and Kailasapathy, K. 2003. Effect of microencapsulation on oxygen toxicity in probiotic bacteria. Aust. $J$. Dairy Technol., 58: 36-39.

Widati, A., Manab, A., and Waluyo, T.H. 2007. The effect of MSG (Monosodium Glutamate) addition on the quality of yoghurt frozen culture starter viewed viability, $\mathrm{pH}$ value and acidity. J. Ilmu. dan Teknologi Hasil Ternak 2: 6-13.

Zuidam, N.J., and Nedovic, V.A. 2010. Encapsulation Technologies for Active Food Ingredients and Food Processing. Springer. USA.

\section{How to cite this article:}

Gisthananda Madyasta, Purwadi, Imam Thohari and Abdul Manab. 2017. The Viability of Lactobacillus acidophilus Microencapsulated in Ca-Alginate Whey Protein Isolate Glycerol Bead Using Emulsification Method. Int.J.Curr.Microbiol.App.Sci. 6(7): 1373-1380. doi: https://doi.org/10.20546/ijcmas.2017.607.164 